\title{
ERRATUM
}

\section{Greenhouse gas emissions from selected Austrian dairy production systems-model calculations considering the effects of land use change-ERRATUM}

\author{
S. Hörtenhuber, T. Lindenthal, B. Amon, T. Markut, L. Kirner, and W. Zollitsch
}

doi:10.1017/S1742170510000025, Published by Cambridge University Press, 12 February 2010.

In Figures 1 and 2, a printing error was made concerning the crosshatching for the bar "By-product beef" in the symbol key. The correct crosshatching for "By-product beef" is $\square$.

\section{Reference}

Hörtenhuber, S., Lindenthal, T., Amon, B., Markut, T., Kirner, L., and Zollitsch, W. 2010. Greenhouse gas emissions from selected Austrian dairy production systems-model calculations considering the effects of land use change. Renewable Agriculture and Food Systems 25:316-329. 